\title{
A new type of papillomavirus DNA, its presence in genital cancer biopsies and in cell lines derived from cervical cancer
}

\author{
Michael Boshart ${ }^{1,3}$, Lutz Gissmann², Hans Ikenberg ${ }^{2}$, \\ Andreas Kleinheinz ${ }^{1}$, Wolfram Scheurlen ${ }^{2}$ and \\ Harald zur Hausen ${ }^{2 *}$ \begin{abstract}
Hermann-Herder-Strasse 11, D-7800 Freiburg 1, and 'Deutsches Krebsforschungszentrum, Im Neuenheimer Feld 280, D-6900 Heidelberg 1, FRG

3Present address: Institut für Klinische Virologie, Loschgestrasse 7, D-8520 Erlangen, FRG

*To whom reprint requests should be sent Communicated by $\boldsymbol{H}$. zur Hausen
\end{abstract} \\ ${ }^{1}$ Institut für Virologie, Zentrum für Hygiene, Universität Freiburg,
}

DNA of a new papillomavirus type was cloned from a cervical carcinoma biopsy. Two EcoRI clones of 7.8 and $6.9 \mathrm{~kb}$ in length were obtained, the latter contained a 900-bp deletion. The BamHI fragments of both clones were used to characterize the DNA. It represents a distinct type of papillomaviruse as determined by its size, its cross-hybridization with DNA of other papillomavirus types under conditions of low stringency only, the co-linear alignment of its genome with HPV 6 and HPV 16 prototypes and its occasional occurrence as oligomeric episomes. We tentatively propose to designate it as HPV 18. DNA hybridizing with HPV 18 under stringent conditions was detected in $9 / 36$ cervical carcinomas from Africa and Brazil, in 2/13 cervical tumors from Germany and 1/10 penile carcinomas. Benign tumors (17 cervical dysplasias, 29 genital warts), eight carcinomata in situ and 15 biopsies of normal cervical tissue were devoid of detectable HPV 18 DNA. HPV 18-related DNA was found, however, in cells of the HeLa, $\mathrm{KB}$ and $\mathrm{C} 4-1$ lines all derived from cervical cancer. The state of the viral DNA was investigated in four cervical cancer biopsies. The data reveal that the DNA might be integrated into the host cell genome. One tumor provided evidence for head to tail tandem repeats some of which persisted as circular episomes.

Key words: human papillomaviruses/genital cancer/molecular cloning/genome integration

\section{Introduction}

Papillomaviruses are known to cause benign proliferations of skin and mucosa revealing the characteristic histological pattern of papillomas or fibropapillomas (for reviews, see Rowson and Mahy, 1967; zur Hausen, 1977). This group of viruses is remarkably heterogeneous and at least 25 distinct genotypes have been identified in man (reviewed by Gissmann and Schwarz, 1984). For many of these types a specific pattern of induced macroscopic and microscopic lesions has been established (Orth et al., 1981).

More recently, evidence has accumulated that certain types of human paillomaviruses (HPV) are closely associated with specific human cancer. In different laboratories the presence of HVP 5 and 8 in cancerous tissues of squamous cell carcinomas arising in patients with epidermodysplasia verruciformis has been demonstrated (Orth et al., 1980; Ostrow et al., 1982; Pfister et al., 1983; G. Orth, personal com- munication). The suspected role of papillomaviruses in human genital cancer (zur Hausen, 1976) received substantial support by recent findings: HPV 6 DNA was demonstrated in non-metastasizing verrucous carcinomas (Buschke-Löwenstein tumors) of the penis and vulva (Gissmann et al., 1982a). In a few biopsies from patients with cervical cancer HPV 10 (Green et al., 1982) or HPV 11 (Gissmann et al., 1983) DNA was demonstrated. Very recently a HPV DNA cloned directly from a cervical cancer biopsy, designated as HPV 16, was demonstrated in a high percentage of cervical, vulval and penile cancer biopsies (Dürst et al., 1983) as well as in clearly precancerous lesions, such as Bowen's disease and Bowenoid papulosis (Ikenberg et al., 1983).

The present report describes the isolation and partial characterization of a new type of HPV DNA isolated from a cervical cancer biopsy. It also analyzes the presence of this DNA in additional cancer biopsies as well as in cell lines derived from cervical cancer.

\section{Results}

Cloning of a new type of human papillomavirus DNA from a cervical carcinoma biopsy

A large number of cervical carcinoma biopsies obtained from various geographic regions was screened for the presence of HPV 8, 9, 10 and 11-related sequences by low stringency hybridization. By southern blotting, DNA from one tumor from a Brazilian patient (WV-341) revealed after EcoRI digestion two bands (7.8 and $6.9 \mathrm{~kb})$, after BamHI cleavage three bands (16, 6.7 and $5.8 \mathrm{~kb})$, (Figure 1). After washing the filters at conditions of higher stringency $\left(T_{\mathrm{m}}-30^{\circ} \mathrm{C}\right.$ or $T_{\mathrm{m}}-18^{\circ} \mathrm{C}$, respectively), the $16-\mathrm{kb}$ and subsequently the $6.7-$ and 5.8-kb fragments were no longer detectable (Figure 1).

A genomic library was constructed from the BamHIrestricted tumor DNA using $\lambda \mathrm{L} 47$ as vector. Screening with a radioactive mixture of HPV 8, 9, 10 and 11 DNA under non-stringent conditions revealed a number of recombinant phages containing either the $6.7-\mathrm{kb}$ or the $5.8-\mathrm{kb}$ Bam HI fragments (K51 and K50 shown in Figure 2, lanes a). Both of these sequences were present within the tumor DNA at high copy number ( $\sim 50-100$ copies per diploid cell). They are closely related to each other as shown by cross-hybridization under stringent conditions (Figure 2). No hybridization was noted with DNA from human embryonic fibroblasts (Figure 2 , lane c) even at a sensitivity permitting the detection of less than one genome equivalent or at conditions of low stringency (data not shown).

The 16-kb BamHI fragment, detected in the original tumor under conditions of low stringency of hybridization, did not hybridize with one of the cloned fragments even at low stringency. Thus, it appears to be an entirely unrelated sequence which has not yet been further characterized. Cleavage maps constructed for the 6.7- and 5.8-kb fragments revealed the identity of both fragments except for a deletion of $\sim 900 \mathrm{bp}$ in the smaller fragment (Figure 3). Mapping of this deletion was possible within $\pm 180 \mathrm{bp}$ (see legend of Figure 3 ). 


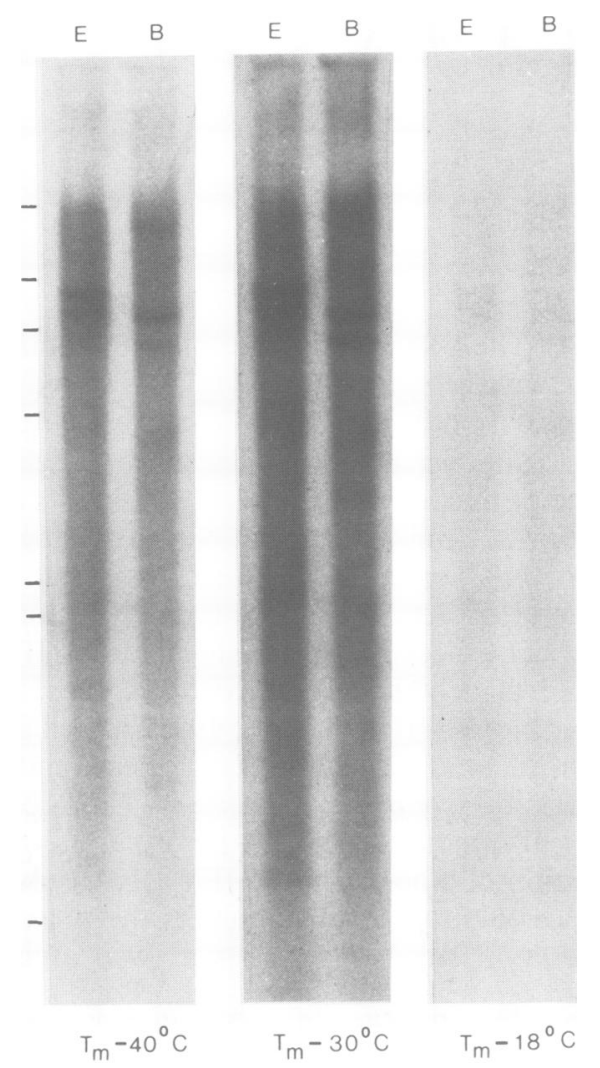

Fig. 1. Blot hybridization at low stringency conditions using a ${ }^{32} \mathrm{P}$-labelled mix of HPV 8, 9, 10 and 11 with WV 341-tumor DNA restricted with EcoRI (lanes E) or BamHI (lanes B). The filter was washed at $40^{\circ} \mathrm{C}$ below melting temperature $\left(T_{\mathrm{m}}\right)$ of DNA (left) and re-washed at $30^{\circ} \mathrm{C}$ below $T_{\mathrm{m}}$ after the first exposure (middle) and again re-washed at $18^{\circ} \mathrm{C}$ below $T_{\mathrm{m}}$ (right). Exposure times, corrected for ${ }^{32} \mathrm{P}$-decay, were 10 times longer for the second and third exposure in order to clearly demonstrate the disappearance of bands. Length marker is $\lambda$ DNA cleaved with HindIII (23 696 bp, 9636 bp, 6636 bp, 4333 bp, 2257 bp, 1985 bp, 561 bp).

After cleaving the cellular DNA of WV-341 with EcoRI and annealing it under stringent conditions with the cloned BamHI 6.7-kb fragment, two bands of 7.8 and $6.0 \mathrm{~kb}$ in size were detected. Both sequences were molecularly cloned and characterized. A comparative restriction enzyme analysis revealed that the 7.8-kb sequence encompasses the $6.7-\mathrm{kb}$ probe, whereas the 6.9-kb sequence contains the deletion of $\sim 900$ bp (Figure 3).

In subsequent experiments, unless indicated, the $6.7-\mathrm{kb}$ Bam HI fragment was used as probe. Hybridization of this DNA with cloned DNA derived from other human papillomavirus types under conditions of low stringency revealed some relatedness with HPV 1-6 and HPV 8-17 which was slightly more pronounced with HPV types $2,3,6,10,11,13$ and 16. A small degree of homology was discernible after hybridization with HPV 2 DNA even under stringent conditions (data not shown). The new DNA is tentatively designated as HPV 18.

A co-linear arrangement of the HPV $6 \mathrm{~b}$ genome (de Villiers et al., 1981; Schwarz et al., 1983) and the BamHI fragment of the new isolate, representing $86 \%$ of the genome, was demonstrated by annealing purified subgenomic fragments under conditions of low stringency (Figure 4). In addition, co-linearity of HPV 18 DNA with the HPV 16 genome could also be demonstrated (data not shown).

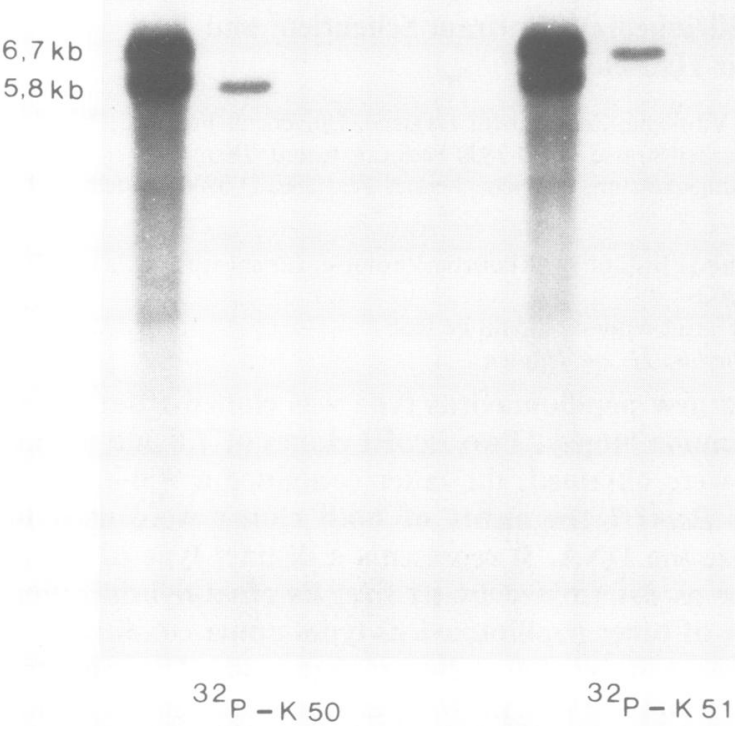

Fig. 2. Blot hybridization at high stringency conditions with two fragments (K50 and K51) cloned from a cervical carcinoma (WV 341). $10 \mu \mathrm{g}$ of total cellular DNA from the tumor biopsy (WV 341) were cleaved with BamHI and electrophoresed in a $0.7 \%$ agarose gel (lanes a). $10 \mu \mathrm{g}$ of DNA extracted from human embryonic lung fibroblasts (HEL) were cleaved with Bam HI and used as control (lanes c). Reconstructions of 10 genome equivalents are shown in lanes $\mathbf{b}(100 \mathrm{pg}$ of the respective cloned fragment mixed with $10 \mu \mathrm{g}$ of BamHI restricted HEL-DNA as carrier). The 5.8-kb Bam HI fragment (K50, left side) and the 6.7-kb Bam HI fragment (K51, right side) purified from the phage vector were used as probes.

\section{HPV 18}

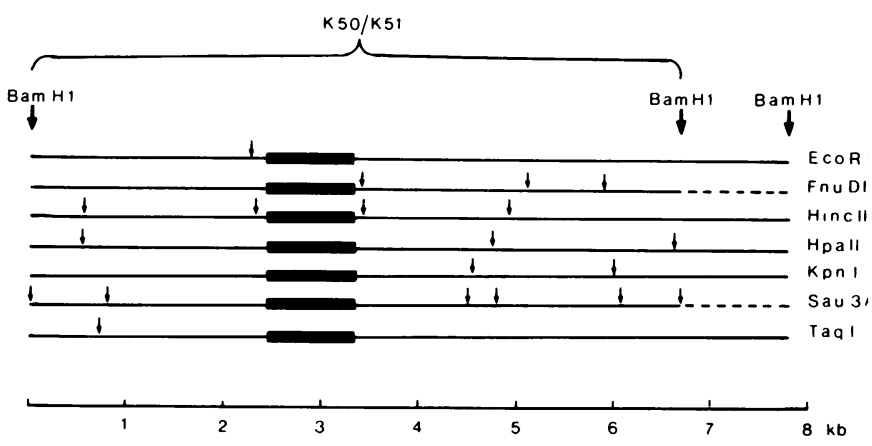

Fig. 3. Physical map of HPV 18 linearized with BamHI. The cloned fragments $\mathrm{K} 50(5.8 \mathrm{~kb})$ and $\mathrm{K} 51(6.9 \mathrm{~kb})$, as indicated, were mapped by analyzing double digests and partial digests. The map was then completed and confirmed by cleavage of WV 341 tumor DNA with the same set of restriction enzymes and subsequent blot hybridization with ${ }^{32} \mathrm{P}$-labelled K51. There might be additional FnuD11 or Sau3A cleavage sites within the HPV 18 portion (dashed line) not covered by the probe used in this experiment (K51). The closed box represents the 900-bp deletion distinguishing K50 from K51. Non-cut enzymes are: BglII, HindIII, SalI, SstI, Xhol. 


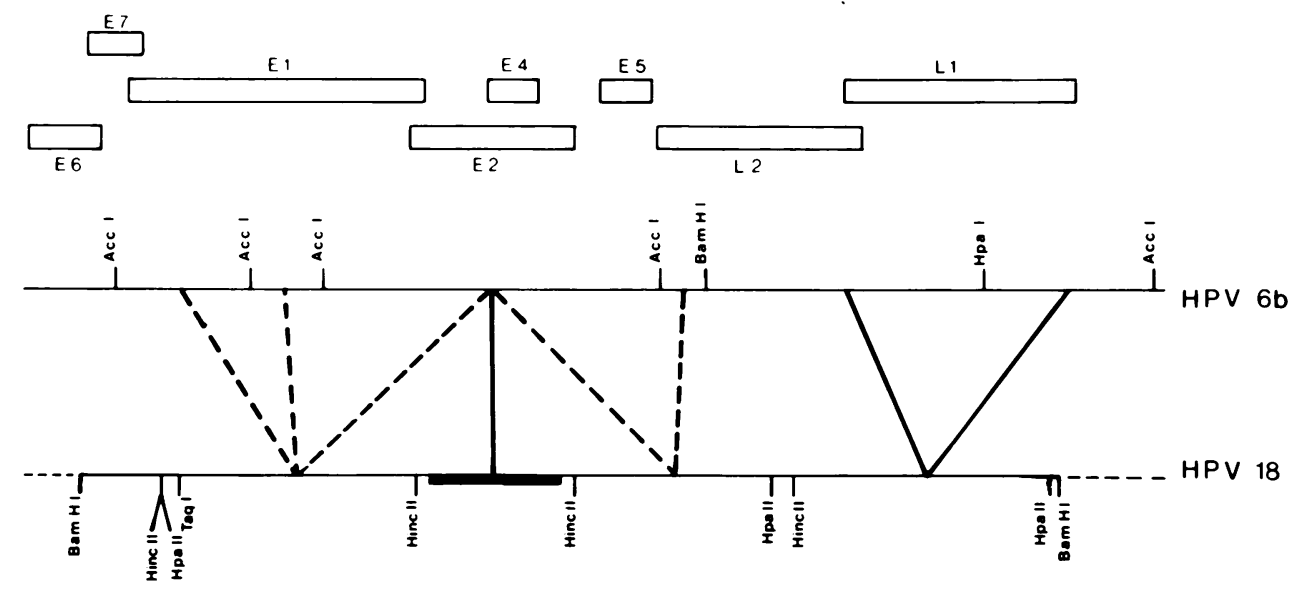

Fig. 4. Co-linearity between HPV 18 and HPV $6 \mathrm{~b}$. The $86 \%$ Bam HI fragment of HPV 18 was cleaved with HincII, TaqI and HpaII. The triple digest was separated on a preparative gel and the four largest fragments were recovered. HPV $6 \mathrm{~b}$ was cut off from the vector with Bam HI and a double digest with $A c$ $c \mathrm{I}$ and $\mathrm{HpaI}$ was subjected to Southern blotting and hybridization under non-stringent conditions with the purified HPV 18 fragments as probes. Crosshybridization between fragments of HPV $6 \mathrm{~b}$ and HPV 18 is indicated. Dashed lines represent weak hybridization. The dashed line in the HPV 18 map represents the small BamHI fragment of HPV 18 not used in this experiment. The 900 -bp deleteion is indicated by a filled box.
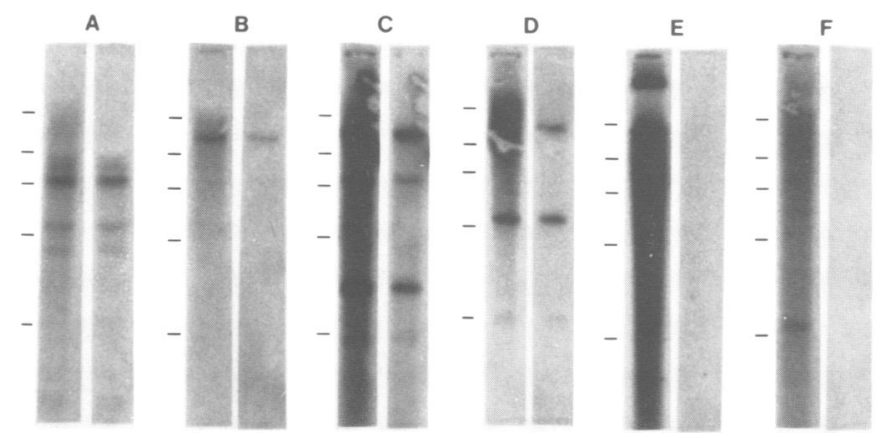

Fig. 5. Detection of HPV 18 sequences in cervical carcinomas. (A) WV 853 from Uganda, (B) WV 1445 from Kenya, (C) WV 1547 from Uganda, (D) WV 1660 from Kenya, (E) WV 858 from Uganda, (F) WV 1443 from Kenya. Total cellular DNA was cleaved with BamHI (A, C, D, F) or EcoRI (B, E), electrophoresed in $1 \%$ agarose gels and blot hybridized under low stringency conditions $\left(T_{\mathrm{m}}-40^{\circ} \mathrm{C}\right)$ with ${ }^{32} \mathrm{P}$-labelled $86 \% \mathrm{HPV}$ 18 fragments (left lanes). Filters were then re-washed at stringent conditions $\left(T_{\mathrm{m}}-18^{\circ} \mathrm{C}\right)$ and re-exposed for exactly the same time (right lanes). A-D contain HPV 18 sequences, whereas $\mathbf{E}$ and $\mathbf{F}$ harbor related papillomavirus sequences as indicated by the absence of hybridization at high stringency conditions. For mol. wt. of the length markers see Figure 1.

\section{HPV 18 sequences in tumor biopsy material}

A number of cervical carcinoma biopsies as well as benign genital tumors and normal cervical tissue were examined by Southern blot analysis for the presence of HPV 18 DNA. Hybridization at low stringency followed by subsequent washing at high stringency after the first exposure (Dürst $e t$ $a l ., 1983)$ permitted the detection of HPV 18-specific as well as that of related sequences within the same experiment (Figure 5). As shown in Table I, DNA from nine out of 36 cervical carcinomas originating from Africa or Brazil reacted with HPV 18 DNA under stringent conditions. DNA from five additional tumors was positive at conditions of low stringency only. Two out of 13 cervical carcinomas from German patients reacted with HPV 18 DNA under stringent conditions. Cervical carcinomata in situ, dysplasias as well as seven biopsies from vulval cancer were negative for HPV 18 DNA. One penile carcinoma obtained from a Brazilian patient was particularly interesting, since it represents the only sample thus far identified containing simultaneously HPV 18 and HPV 16 sequences.
Twenty-nine biopsies from genital warts (condylomata acuminata), including five samples from African patients, as well as 15 samples from clinically inconspicuous cervical tissue were negative for HPV 18 DNA.

\section{HPV 18 sequences in established cell lines}

DNA obtained from three cell lines (HeLa, KB and C4-1) was tested for the presence of HPV 18 DNA. These lines contain sequences hybridizing with HPV 18 DNA under stringent conditions (Figure 6). It is interesting to note that the size of the hybridizing fragments after digestion with various restriction enzymes is identical in HeLa and KB cells (faint additional bands are seen in KB DNA) supporting earlier observations revealing the HeLa origin of KB cells (Nelson-Rees and Flandermeyer, 1976). HeLa and C4-1 lines have been established from cervical cancer biopsies. Evidence indicative of a covalent integration of the HPV 18-related DNA into the genome of these cells will be presented elsewhere.

\section{Physical state of HPV 18 DNA in cervical tumors}

By digesting WV-341 DNA with six different non-cut enzymes for HPV 18 DNA no discrete bands were discernible in Southern blots after hybridization with HPV 18 DNA (Figure 7). At $\sim 20 \mathrm{~kb}$ some hybridization was visible smearing over a substantial region of the gel. If enzymes cutting HPV 18 DNA once (EcoRI) or several times (BamHI, XbaI) were used, however, hybridization in the high mol. wt. region disappeared and discrete bands became visible. To rule out nonspecific trapping of viral sequences, WV-341 DNA was digested simultaneously with all six non-cut enzymes. This resulted in substantial degradation of cellular DNA as seen after ethidium bromide staining. HPV 18 DNA still hybridized in the high mol. wt. region (data not shown).

Two-dimensional agarose gel electrophoresis according to Wettstein and Stevens (1982) was used to separate circular DNA (nicked and supercoiled) from linear DNA in the high molecular smear of viral DNA shown in Figure 7. As shown in Figure 8, the majority of HPV 18-specific sequences comigrated with linear DNA as evidenced by superimposition to the trail of cellular DNA stained with ethidium bromide. A minor fraction was resolved as separate spots migrating slower in the second dimension, thus apparently representing circular viral DNA molecules. The two spots with the lowest mol. wt. seen in Figure 8 may represent supercoiled dimers of 


\section{Boshart et al.}

Table I. Occurrence of HPV 18 DNA in genital tumors

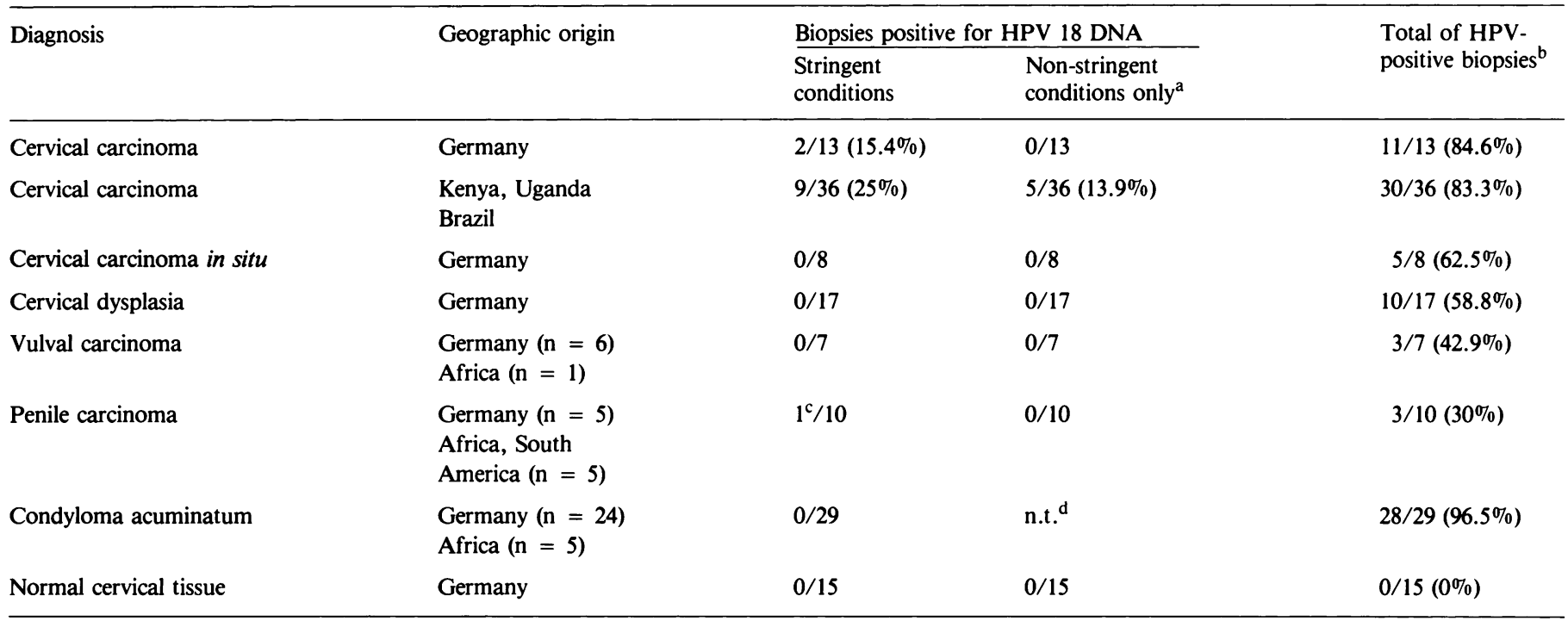

${ }^{a}$ All biopsies revealing the same fragment pattern as with HPV 16 under stringent conditions were not counted as positives, since HPV 18 and HPV 16 crosshybridize under non-stringent conditions.

${ }^{b}$ Positive under non-stringent or stringent conditions with ${ }^{32}$ P-labelled HPV 6, 10, 16, 18, respectively, data taken from Ikenberg et al., in preparation.

c Contains HPV 16 and HPV 18 sequences.

d Not tested.

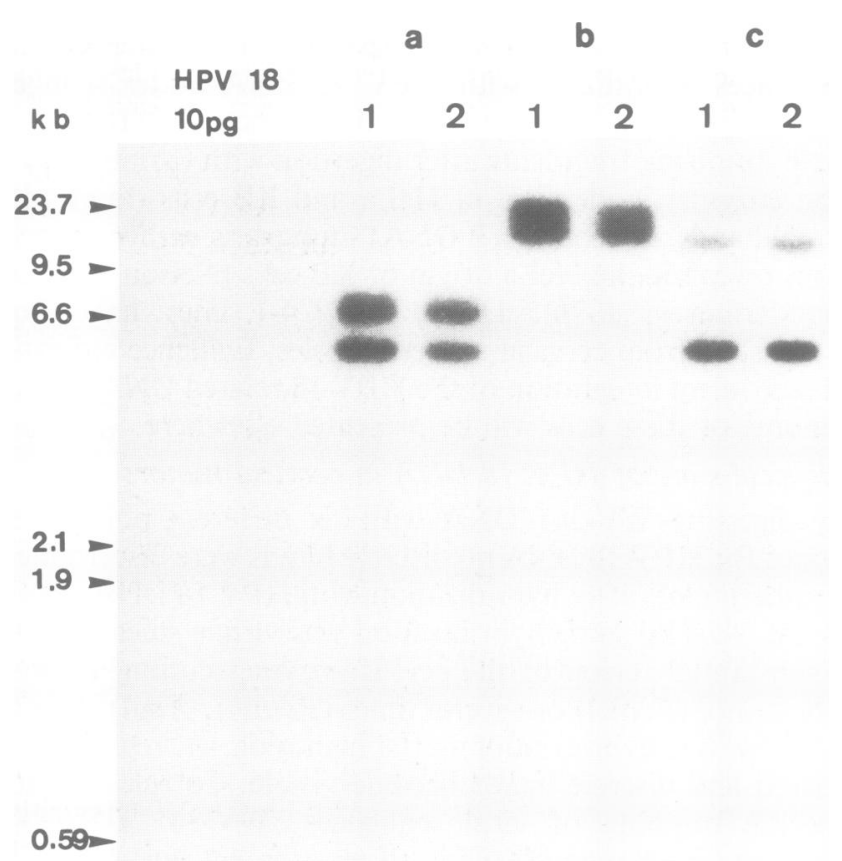

Fig. 6. Blot hybridization of cellular DNA extrtacted from KB (1) or HeLa cells (2) after cleavage with HindIII (a), EcoRI (b) and BamHI (c) with 32P-labelled HPV 18 DNA (EcoRI clone, representing the complete genome) under stringent conditions. $10 \mathrm{pg}$ of the 5.8-kb Bam HI fragment (K50) of HPV 18 were included as sensitivity marker.

Fig. 7. Blot hybridization of WV 341 DNA with the $86 \%$ HPV 18 fragment under stringent conditions. $2 \mu \mathrm{g}$ of DNA were digested with the enzyme indicated on top of each lane and separated on a $0.4 \%$ agarose gel. For mol. wt. of the length markers see Figure 1. 


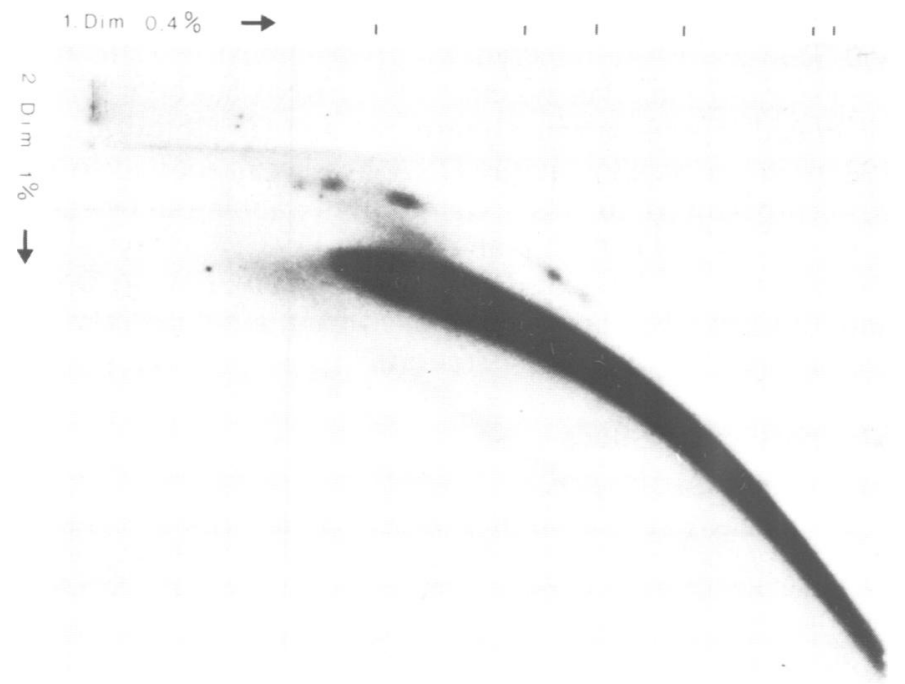

Fig. 8. Analysis of HPV 18 DNA by two-dimensional gel electrophoresis. WV 341 tumor DNA $(10 \mu \mathrm{g})$ was double digested with two non-cut enzymes ( $\mathrm{XhoI}$ and $\mathrm{Sall}$ ) and electrophoresed in $0.4 \%$ agarose (first dimension) and $1 \%$ agarose (second dimension). A Southern blot was then prepared and hybridized with the $86 \%$ HPV 18 fragment. Circular oligomeric molecules are visible as separate distinct spots. For mol. wt. of the length markers see Figure 1.
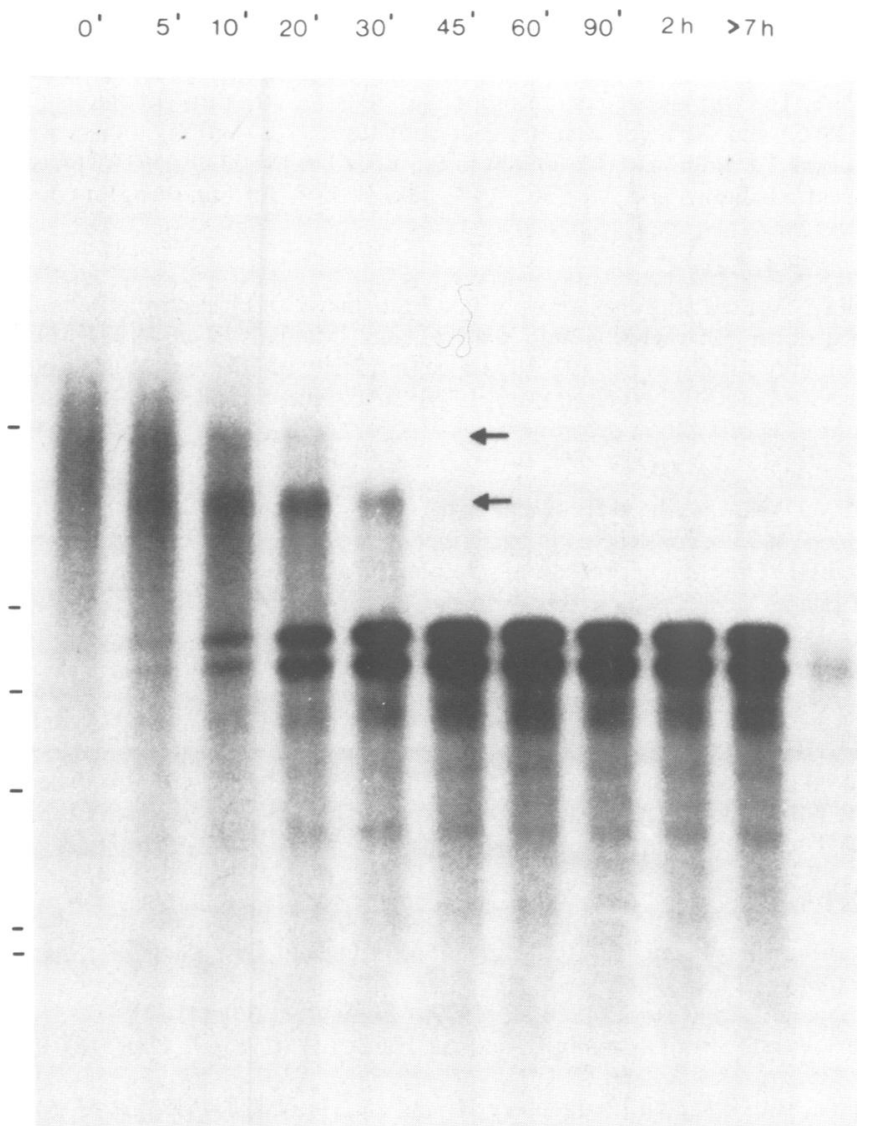

Fig. 9. Partial digestion of WV 341 DNA with EcoRI. The reaction was started with $20 \mu \mathrm{g}$ DNA and $1 \mathrm{U} / \mu \mathrm{g} E c o$ RI. $2 \mu \mathrm{g}$ aliquots were taken at the times indicated on top of each lane. Reaction was stopped immediately by adding EDTA to $25 \mathrm{mM}$ and chilling on ice. Pre-digestion with a noncut enzyme (Sstl) was performed in order to obtain good separation on a $0.4 \%$ gel. Linear dimers $(\sim 15 \mathrm{~kb})$ and trimers $(\sim 22 \mathrm{~kb})$ are indicated by arrows. For mol. wt. of the length markers see Figure 1.

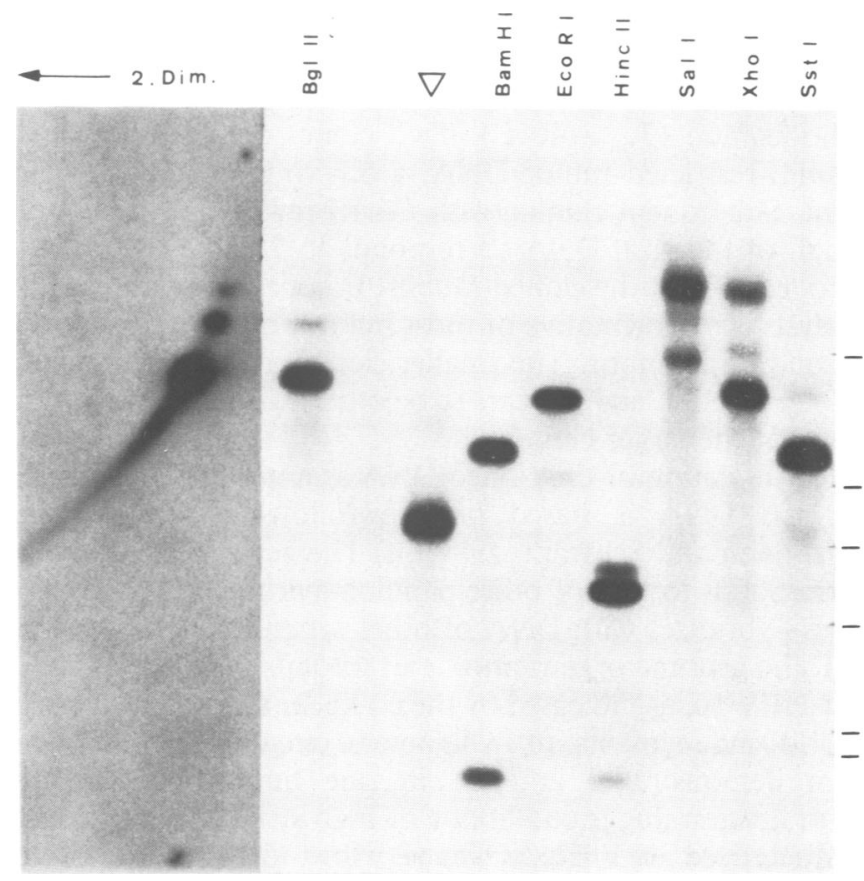

Fig. 10. Blot hybridization under stringent conditions of DNA from the cervical carcinoma WV 1661 with ${ }^{32}$ P-labelled $86 \%$ HPV 18 fragment. Total cellular DNA was digested with the restriction enzymes indicated on top of each lane and separated on a $0.4 \%$ agarose gel. The $B g / I I$ digest was run in a second dimension into $1 \%$ agarose (left side). No circular molecules could be detected. The $86 \%$ HPV 18 fragment $(6.7 \mathrm{~kb})$ was run in parallel (lane $\nabla$ ). For mol. wt. of the length markers see Figure 1.

HPV $18(7.8 \mathrm{~kb})$ and of the deleted molecules $(6.9 \mathrm{~kb})$, respectively, as calculated from the mobility of circular marker DNAs (not shown). No monomeric forms of HPV 18 DNA were detected.

After digestion with single or multi-cut restriction enzymes the same fragments as expected from the physical map (see Figure 3) were demonstrated within the tumor. Since this DNA contains a high copy number of viral genome equivalents, the presence of viral DNA in head-to-tail tandem repeats is suggesed. The demonstration of linear dimers and trimers after partial digestion of tumor DNA (Figure 9) provides direct evidence for tandem repetition. A number of submolar bands are visible in Figure 9 migrating faster than unitlength viral DNA. They did not change in mobility when WV-341 was digested with EcoRI in combination with noncut enzymes. Thus, although very likely, no direct evidence is available for an integration of viral DNA into the host cell genome of this tumor. In three additional HPV 18-positive tumors, however, cleavage with single as well as with multicut enzymes provided patterns different for all tumor DNAs. Discrete bands were also obtained after cleavage with non-cut enzymes for one of these tumors (Figure 10). Since the cleavage pattern varied by using different non-cut enzymes and since most of the bands migrated slower than unit length viral DNA, integration of viral DNA into the host cell genome should be the most likely explanation. This is further supported by two-dimensional electrophoresis of cellular DNA which did not reveal evidence for the presence of circular viral DNA (Figure 10).

\section{Discussion}

This report describes a new type of papillomavirus DNA isolated from a cervical cancer biopsy. Similar to previous 
studies (Gissmann et al., 1982b; Dürst et al., 1983), the DNA was cloned by using different types of papillomavirus DNA as probes and by applying conditions of low stringency of hybridization $\left(T_{\mathrm{m}}-40^{\circ} \mathrm{C}\right)$. Two clones are obtained from BamHI-restricted tumor DNA, a $6.7-\mathrm{kb}$ and a $5.8-\mathrm{kb}$ fragment. Subsequent cloning with EcoRI revealed that the total length of the viral DNA corresponds to 7.8 and $6.9 \mathrm{~kb}$, respectively. Thus, the cloned BamHI fragment used for further analysis is representative of most but not of all specific DNA found in this tumor. The smaller cloned molecule contains a 900-bp deletion and appears to be otherwise identical with the DNA of the larger clone.

Identification of the cloned DNA as a new type of papillomavirus DNA is based on the following characteristics (Gissmann and Schwarz, 1984). (i) The genome size (7.8 kb) corresponds to that of other papillomaviruses. (ii) The DNA cross-hybridizes with DNA of other types of HPV genomes. (iii) The genome organization corresponds to that of HPV 6 and HPV 16, as indicated by the co-linear alignment of crosshybridizing segments. (iv) Oligomeric circular molecules have been demonstrated at least in one tumor. Since crosshybridization under conditions of high stringency with other characterized HPV DNAs was very low, identification of this DNA as a new type (tentatively designated as HPV 18) seems to be justified (Coggin and zur Hausen, 1979).

The presence of this viral DNA in cervical cancer biopsies, in one penile cancer biopsy as well as in certain cell lines derived from cervical cancer is interesting. Up to now HPV 6 DNA has been detected in invasively growing, non-metastasizing verrucous carcinomas (Buschke-Löwenstein tumors) of penis and vulva (Gissmann et al., 1982a), HPV 10 DNA and HPV 11 DNA in a small number of anogenital and cervical cancer biopsies (Green et al., 1982; Gissmann et al., 1983) and HPV 16 DNA in a relatively high percentage of genital cancer biopsies (Dürst et al., 1983). In comparison with other genital papillomavirus infections, HPV 16 and HPV 18 reveal some remarkable features: they exhibit a surprisingly specific association with malignant genital tumors. HPV 18 thus far has been exclusively detected within malignant tissue, HPV 16 is also regularly present in premalignant 'high-risk' lesions, such as Bowen's disease, Bowenoid papulosis, severe atypia and carcinoma in situ of the cervix (Ikenberg et al., 1983; and in preparation). By analyzing the same tumor biopsies for HPV 16 and HPV 18 DNA, $>70 \%$ prove to be positive under stringent conditions of hybridization (Ikenberg et al., in preparation). Since additional tumors hybridize with probes under low stringency conditions only (see Table I), it appears that human genital cancer is rather regularly associated with papillomavirus infections.

Human cervical cancer cell lines containing HPV 18 DNA are excellent tools for the further analysis for HPV 18 gene regulation. It is particularly interesting that comparison of HeLa cell DNA as well as of DNA from the HeLa-derived cell line KB reveals the presence of HPV 18-specific sequences without major structural reorganization. Since no lines have yet been obtained containing HPV 16 DNA, it could be considered whether the presence of HPV 18 DNA promotes an easier establishment of lines in tissue culture.

The studies on the physical state of HPV 18 DNA indicate its presence in tandem repeats and suggest its frequent integration within the host cell genome. The presence of crossreacting, but different sequences within these tumors, however, cannot be entirely ruled out. Although many papillomavirus infections lead to persistence of viral DNA in an episomal state (for review, see Pfister, 1984; Gissmann and Schwarz, 1984), integration of papillomavirus DNA has been suggested in other systems. BPV 1 DNA has been found integrated in one hamster tumor cell line (Breitburd et al., 1981). Shope papillomavirus DNA has been reported to be covalently linked to host cell DNA in rabbit tumors and tumor cell lines (Wettstein and Stevens, 1982; McVay et al., 1982). Recently, junction fragments between HPV 16 DNA and host cell DNA have been cloned from a human cervical tumor (Dürst et al., in preparation).

\section{Materials and methods}

Biopsies and extraction of DNA

Tumor biopsies were obtained from several hospitals. They were usually stored at $-70^{\circ} \mathrm{C}$. Diagnosis had been established by histological examination. High mol. wt. DNA was extracted from tissue samples as described before (zur Hausen et al., 1970).

\section{Restriction enzyme cleavage and blot hybridization}

Restriction endonucleases were purchased from New England Biolabs or Bethesda Research Laboratories and used according to the recommendations made by the suppliers. Usually $10 \mu \mathrm{g}$ of cellular DNA were electrophoresed in horizontal $0.4-1 \%$ agarose gels using $40 \mathrm{mM}$ Tris-acetate, $2 \mathrm{mM}$ EDTA (pH 7.8) as running buffer. DNA was transferred onto nictrocellulose filters (Schleicher and Schuell) by the method of Southern (1975).

Pre-hybridization solution contained: $5 \times$ SSC $(1 \times$ SSC is $0.15 \mathrm{M} \mathrm{NaCl}$, $0.015 \mathrm{M}$ sodium citrate), $50 \mathrm{mM}$ sodium phosphate buffer $(\mathrm{pH} 6.5), 0.02 \%$ polyvinylpyrolidon, $0.02 \%$ bovine serum albumin, $0.02 \%$ Ficoll 400 , $0.5 \mathrm{mg} / \mathrm{ml}$ denatured tRNA and the formamide concentration as given below.

Hybridization was performed at $42^{\circ} \mathrm{C}$ in the same solution containing $20 \mathrm{mM}$ sodium phosphate buffer $(\mathrm{pH} 6.5), 0.1 \mathrm{mg} / \mathrm{ml}$ tRNA and the labelled DNA. The formamide concentration was $50 \%$ for stringent conditions $\left(T_{\mathrm{m}}\right.$ $\left.-18^{\circ} \mathrm{C}\right)$ and $20 \%$ for non-stringent conditions $\left(T_{\mathrm{m}}-40^{\circ} \mathrm{C}\right)$. Filters were washed $2 \times 5 \mathrm{~min}$ and $3 \times 30 \mathrm{~min}$ in $0.6 \times \mathrm{SSC}, 0.1 \% \mathrm{SDS}$ at $63^{\circ} \mathrm{C}$ for stringent conditions and $2 \times \mathrm{SSC}, 0.1 \% \mathrm{SDS}$ at $50^{\circ} \mathrm{C}$ for non-stringent conditions.

\section{Labelling of $D N A$}

All DNAs used as probes were purified from the vector by electrophoresis and subsequent electroelution into dialysis bags (Maniatis et al., 1982). Nick translation (Rigby et al., 1977) to a specific activity of $10^{8}$ c.p.m. $/ \mu \mathrm{g}$ has been described previously (Fresen et al., 1979). $10^{5}$ c.p.m. $/ \mathrm{cm}^{2}$ filter area were used in most hybridization experiments.

Cloning of viral $D N A$

HPV DNA was cloned from a genomic library of a tumor DNA (laboratory code WV-341), constructed in bacteriophage vector $\lambda$ L47 after cleavage with BamHI. The cloning procedure, screening of recombinants and propagation of phages have been described before (Gissmann et al., 1982b).

\section{Acknowledgements}

We are grateful to Dr. G. Orth for his help in typing the HPV 18 DNA and to Drs. B. Fleckenstein and H. Pfister for critical reading of this manuscript. The skilful technical assistance of Miss F. Schreiber is gratefully acknowledged. This work was supported by the Deutsche Forschungsgemeinschaft (SFB 31: Tumorentstehung und -entwicklung).

\section{References}

Breitburd,F., Favre,M., Zoorob,R., Fortin,D. and Orth,G. (1981) Int. J. Cancer, 27, 693-702.

Coggin,J.R. and zur Hausen,H. (1979) Cancer Res., 39, 545-546.

de Villiers,E.-M., Gissmann,L. and zur Hausen,H. (1981) J. Virol., 40, 932935.

Dürst,M., Gissmann,L., Ikenberg,H. and zur Hausen,H. (1983) Proc. Natl. Acad. Sci. USA, 80, 3812-3815.

Fresen,K.O., Cho,M.S., Gissmann,L. and zur Hausen,H. (1979) Intervirology, 12, 303-310.

Gissmann,L. and Schwarz,E. (1984) in Becker,Y. (ed.), Development in Molecular Virology, Vol. 5, Recombinant DNA, Martinus Nijhoff Publishers, Hingham, MA, in press.

Gissman,L., de Villiers,E.-M. and zur Hausen,H. (1982a) Int. J. Cancer, 29, 143-146.

Gissmann,L., Diehl,V., Schultz-Coulon,H.J. and zur Hausen,H. (1982b) J. Virol., 44, 393-400. 
Gissmann,L., Wolnik,L., Ikenberg,H., Koldovsky,U., Schnürch,H.G. and zur Hausen,H. (1983) Proc. Natl. Acad. Sci. USA, 80, 560-563.

Green,M., Brackmann,K.H., Sanders,P.R., Loewenstein,P.M., Freel,J.H., Eisinger,M. and Switlyk,S.A. (1982) Proc. Natl. Acad. Sci. USA, 79, 4437-4441.

Ikenberg,H., Gissmann,L., Gross,G., Grussendorf-Conen,E.I. and zur Hausen,H. (1983) Int. J. Cancer., 32, 563-566.

Maniatis,T., Fritsch,E.F. and Sambrook,J. (1982) Molecular Cloning: $A$ Laboratory Manual, published by Cold Spring Harbor Laboratory Press, NY.

McVay,P., Fretz,M., Wettstein,F., Stevens,J. and Ho,Y. (1982) J. Gen. Virol., 60, 271-278.

Nelson-Rees,W.A. and Flandermeyer,R.R. (1976) Science (Wash.), 195, 9698.

Orth,G., Favre,M., Breitburd,F., Croissant,O., Jablonska,S., Obalek,S., Jarzabek-Chorzelska,M. and Rzesa,G. (1980) Cold Spring Harbor Conf. Cell. Prolif., 7, 259-282.

Orth,G., Jablonska,S., Favre,M., Croissant,O., Obalek,S., Jarzabek-Chlorzelska,M. and Jibard,N. (1981) J. Invest. Dermatol., 76, 97-102.

Ostrow,R.S., Bender,M., Niimura,M., Seki,T., Kawashima,M., Pass,F. and Faras,A.J. (1982) Proc. Natl. Acad. Sci. USA, 79, 1634-1638.

Pfister,H. (1984) Rev. Physiol. Biochem. Pharmacol., 99, 111-181.

Pfister,H., Gassenmaier,A., Nürnberger,F. and Stüttgen,G. (1983) Cancer Res., 43, 1436-1441.

Rigby,P.W.J., Dieckmann,M., Rhodes,C. and Berg,P. (1977) J. Mol. Biol., 113, 237-252.

Rowson,K.E.K. and Mahy,B.W.J. (1967) Bacteriol. Rev., 31, 110-131.

Schwarz,E., Dürst,M., Demankowski,C., Lattermann,O., Zech,R., Wolfsperger,E., Suhai,S. and zur Hausen,H. (1983) EMBO J., 2, 2341-2348.

Southern,E.M. (1975) J. Mol. Biol., 98, 503-517.

Wettstein,F.O. and Stevens,J. (1982) Proc. Natl. Acad. Sci. USA, 79, 790794.

zur Hausen,H. (1976) Cancer Res., 36, 530.

zur Hausen,H. (1977) Curr. Top. Microbiol. Immunol., 78, 1-30.

zur Hausen,H., Schulte-Holthausen,H., Klein,G., Henle,G., Henle,W., Clifford,P. and Santesson,L. (1970) Nature, 228, 1056-1058.

Received on 5 January 1984; revised on 15 February 1984 